\title{
Strata Management Tribunal in Peninsular Malaysia: Comparison to Strata Titles Board, Singapore and Consumer Trade Tenancy Tribunal, New South Wales, Australia
}

\author{
Mazliza Mohamad \\ Lecturer, Faculty of Law, Universiti Kebangsaan Malaysia \\ mazliza@ukm.edu.my
}

\author{
Ahmad Azam Mohd Shariff \\ Associate Professor, Faculty of Law, Universiti Kebangsaan Malaysia \\ aazam@ukm.edu.my \\ Safinaz Mohd Hussein \\ Associate Professor, Faculty of Law, Universiti Kebangsaan Malaysia \\ finaz@ukm.edu.my \\ Ramalinggam Rajamanickam \\ Lecturer, Faculty of Law, Universiti Kebangsaan Malaysia \\ rama@ukm.edu.my
}

Doi:10.5901/mjss.2015.v6n2p293

\section{Abstracts}

Part IXA of the Strata Titles Act 1965 ("STA") provides for the establishment of the Strata Titles Board ("STB"). STB is given the mandate to exercise quasi-judicial functions with regards to matters relating to multi storey buildings. The rationale for establishing the STB is to protect the interest of the parcel owners. However, the STB shall be abolished with the proposed enactment of the Strata Management Act 2013 ("SMA"). In line with Section 102 of the new Strata Management Act, the STB will be replaced with the Strata Management Tribunal ("SMT") in accordance with Part XI of the SMA. In theory, it is anticipated that the establishment of the SMT will address the strata titles management disputes particularly with regards to the failure on the part of the parcel owners to pay maintenance fees and issues on the election of their committee members. The aimed of this paper is to discuss the SMT in accordance with Part XI of the SMA with comparison to the STB, Singapore and the three (3) tiered dispute resolution processes in New South Wales, Australia. The objective of this paper is to see whether the provisions in SMA with regards to the establishment of the SMT is comparatively sufficient as provisions in the legislations of Singapore and New South Wales, Australia to address the strata titles management disputes. The research method used in writing up this paper is the qualitative research in which it will rely on the analysis of the relevant statutes, rules, regulations, books, journals, articles, thesis, seminar papers, electronic materials and various newspaper reports. The finding of this paper is that the provisions of the SMA regarding the establishment of the SMT together with the regulations to regulate the SMT may be sufficient to resolve the strata titles management disputes in a more expedient manner. It is hoped that any disputes shall be resolved more timely and efficiently with minimal costs since the parties in dispute can submit a case or claim before the SMT since not all matters may necessarily be taken to court in order for it to get resolved.

Keywords: multi storey buildings; Strata Management Tribunal; strata titles management

\section{Introduction}

The new Strata Management Act 2013 ("SMA") received its Royal Assent on $5^{\text {th }}$ February, 2013 and was gazetted on $8^{\text {th }}$ February, 2013 which is now known as Act 757. The main objective of the SMA was to govern the maintenance and management of buildings and common property of multi storey buildings and subdivided lands into a single piece of legislation. The Act went through three (3) years of vigorous and stringent drafting in order to safeguard the interests and rights of the parcel owners. The Act's sole interest and main objective was to protect parcel owners; especially in order to ensure that there is proper maintenance and management of the building and common property free from unscrupulous 
developers and illegal property managers (Ishak, 2012).

Hence, the Strata Titles Board ("STB") which was legalised under the STA shall be abolished with the proposed enactment of the SMA. Thus, in accordance with section 102 of the SMA, the STB shall be replaced with the Strata Management Tribunal ("SMT") in accordance with Part XI of the SMA. It is anticipated that with the SMT's establishment, this in itself will theoretically help to address all of the strata titles management disputes.

As the result of the establishment of the SMT, the strata titles management disputes are expected to be resolved in a more expedient manner and that not all matters necessarily be taken to court in order for it to get resolved. Hence, it is expected that any disputes shall be resolved more timely and efficiently with minimal costs since the parties in dispute can submit a case or claim before the SMT. In that respect, it is relevant to note that there are currently not many tribunals established in Malaysia. There are two (2) tribunals which are currently in existence, namely the Consumer Tribunal and the Homebuyers' Claims Tribunal which are established under the Consumer Protection Act 1992 and the Housing Development (Control and Lisencing) Act 1966 respectively (Azlinor, 2012; Cecil, 2013; Azian, 2013; Samsar, 2002).

In contrast to the position in the New South Wales, Australia, the disputed party shall go through a three (3) tiered formal process of dispute resolution. Firstly, as provided in Section 125 of the SSMA, NSW the disputing parties are compulsorily required to attempt and resolve their dispute through mediation. Section 127 of the SSMA, NSW provides that "mediation" means a structured negotiation process in which the mediator, as a neutral and independent party, assists the parties to a dispute to achieve their own resolution of the dispute. The said compulsorily mediation is usually conducted by the NSW Fair Trading, although the parties in dispute may opt to use another mediation service to resolve their dispute. In the event that the mediation fails, an application for adjudication to the Consumer Trade Tenancy Tribunal ("CTTT") can be made and the decision is made and published on the papers. In this regards, there is no hearing during the adjudication process and the disputed parties are to lodge their written submissions to support their case. Any party who is dissatisfied with an Adjudicator's decision is able to appeal through the Tribunal (Moore, 2006; Sharon, Anne, 2006).

However, the position in Singapore is very much different to Australia. In Singapore, any dispute with regards to strata titles management shall be resolved by the Strata Titles Boards which was officially established with the enactment of a new Part VI in the then Land Titles (Strata) Act 1967 by the Land Titles (Strata) (Amendment) Act 1987. The STB, Singapore played a significant role to encourage amicable dispute resolution. STB's role has since evolved and grown. In 1998, the Land Titles (Strata) Amendment Bill was amended to remove the need for unanimous consent for en bloc sales (Alice, 2013; Christudason, 2013; Christudason, 2005; Alice, 2005; Christudason, 2009; Alice, 2010; Alice, 1996; Christudason, 2008). In 1999, STB's role was expanded to include mediation and adjudication in en bloc sales. It acts as a platform for minority owners who do not wish to proceed with an en bloc sale to voice their concerns and resolve the issues without having to incur legal and court fees. STB has performed its expanded role well. In that regards, the current position of STB in Malaysia is similar in many respects to that stipulated in the BMSMA, Singapore (Teo, 2012).

\section{Jurisdiction of Tribunal}

It is essential to note that the SMT is divided into two (2) jurisdictions; the pecuniary and subject matter jurisdictions. At this instance, the SMT shall have the jurisdiction to hear and determine any claims which does not exceed two hundred and fifty thousand ringgit $(\mathrm{RM} 250,000)$. This is in view of section 105(1) of the SMA. In the writer's view, this is commercially a significant amount. This is because the said amount can be considered reasonable and deemed suitable given the current value of the property prices, which continues to be increasing every year that passes by. In addition to that, it is viewed that the said amount will be practical since there could be claims which are collectively made by numerous parcel owners and their claim may collectively total up to two hundred and fifty thousand ringgit (RM250,000).

It is also relevant to note that the pecuniary jurisdiction stipulated on the SMT can be considered to be very high in comparison to the Consumer Tribunal which is only twenty five thousand ringgit (RM25,000) and the Homebuyers' Tribunal Claim which is fifty thousand ringgit (RM50,000). This is in view of Section 98(1) of the Consumer Protection Act 1999 and Section 16M of Housing Development (Control and Licensing) Act 1966 respectively. On the other hand, the argument to this would be on the basis of the current market value of the property which keeps on rising in Malaysia and that makes the pecuniary jurisdiction of the SMT amounting to two hundred and fifty thousand $(\mathrm{RM} 250,000)$ could be deemed as sufficient.

The SMA clearly provides that the SMT has no jurisdiction to hear any claim with regards to the title to any land or any estate or interest in land or any franchise is in question (Section 105(3) of the SMA). The writer is of the view that this is considered as a positive development of the SMA to clearly demarcate the area that the SMT is in power. As reflected 
in the name of the Tribunal, the matter to be filed in the SMT would be matters solely pertaining to the strata titles management. In addition, the SMT is a quasi-judicial body which is aimed at having a simple and inexpensive mechanism in adjudicating disputes in strata titles management (Azlinor, 2012). In view of the above discussion, matters with regards to the delay in issuance of the strata titles, dispute of ownership to the parcel or other complicated legal issues with regards to strata titles may not be filed before the SMT since it requires more formal and technical procedures which is more appropriate to be brought before the court. This position is similar to that in Singapore whereby Section 95 of the BMSMA clearly stipulates that the Board shall not have any jurisdiction regarding title to land. However, the provision in the BMSMA, Singapore and SSMA, NSW, Australia, do not stipulate the pecuniary jurisdiction of the Strata Titles Board, Singapore and the CTTT, NSW respectively.

Section 105(1) of the SMA has also listed down in the Fourth Schedule the subject matter of dispute in which the SMT has jurisdiction:

i. A dispute or complaint concerning an exercise or the performance of, or the failure to exercise or perform, a function, duty or power conferred or imposed by this Act or the by-laws, except for those specifically provided in this Part,

ii. Subject to subsection 16N(2) of the Housing Development (Control and Licensing) Act 1966 [Act 118], a dispute on costs or repairs in respect of a defect in a parcel, building or land intended for subdivision into parcels, or subdivided building or land, and its common property or limited common property,

iii. A claim for the recovery of Charges or contribution to the sinking fund, or any amount which is declared by the provisions of this Act as a debt,

iv. A claim for an order to convene a general meeting,

V. A claim for an order to invalidate proceedings of meeting where any provision of the Act has been contravened,

vi. A claim for an order to nullify a resolution where voting rights has been denied or where due notice has not been contravened,

vii. A claim for an order to nullify a resolution passed at a general meeting,

viii. A claim for an order to revoke amendment of by-laws having regard to the interests of all the parcel owners or proprietors,

ix. A claim for an order to vary the rate of interest fixed by the joint management body, management corporation or subsidiary management corporation for late payment of charges, or contribution to the sinking fund,

x. A claim for an order to vary the amount of insurance to be provided,

xi. A claim for an order to pursue an insurance claim,

xii. A claim for compelling a developer, joint management body, management corporation or subsidiary management corporation to supply information or documents,

xiii. A claim for an order to give consent to effect alterations to any common property or limited common property,

xiv. A claim for an order to affirm, vary or revoke the Commissioner's decision.

It can be deduced from the above discussions that the SMT has been granted with a wide jurisdiction in determining claims from various types of disputes pertaining to strata titles management. Further to that, the SMA, via the first clause under the schedule, has made a positive step in providing a provision which confers discretions on the part of the Chairman of the SMT to determine claims which are anticipated in the future; and these could be isolated claims other than those listed in the Fourth Schedule. In addition to the above points discussed, the SMA may also take into consideration the position of the Singapore and NSW, Australia as a guideline and benchmark. In the Singapore and NSW's jurisdictions, there are various steps taken prior to bringing the dispute to the Tribunal in trying to get the dispute resolved.

The provisions of sections 138-203 of the SSMA, NSW clearly outline the subject matters which may be made to the Tribunal. However, the following types of disputes cannot be taken to mediation or to the CTTT, for instance, a claim by an owner for reimbursement for urgent repairs to common property, a claim for compensation for damage caused to common property, action to recover outstanding levies from owners, disputes involving an owner who wants to do renovations but the scheme is refusing to sign the development application, disputes between owners corporations and managing agents over the terms of the management agreement, disputes involving strata titles management statements and building management committees in the case of a mixed development which is part strata. In view of the above, the disputed parties have to take recovery action through the court system. In that context, it is opined that this may give rise to a costly, lengthy and formal procedure in order to resolve the dispute at hand. Further to that, it will involve two (2) different forums to resolve one (1) dispute. This is due to the fact that in the event that owners corporation has neglected in the maintenance of common property, the unsatisfied party would need to apply for an order for repairs to be carried 
out through the mediation or CTTT process. At the same time, if the damage is caused to the parcel owner's personal property due to the negligence, the claim for compensation must go through the local court.

Similar to the position in Singapore, sections 101-115 of the BMSMA provides the types of orders which the Strata Titles Board can make. The advantage of the position in Singapore is that it is guided by the General Guide provided by Building and Construction Authority, Singapore that in the event there is a dispute, disputed parties should first seek to resolve the problem by discussing together and trying to resolve amicably. Subsequently, if it fails, the parties should seek for mediation by an independent and neutral party. The Building and Construction Authority, Singapore has taken a pro-active step by providing the list of mediation bodies in the General Guide which can be easily accessed by the public. However, the position in Singapore does not make it compulsory on the disputed parties for mediation as opposed to the position in New South Wales, Australia.

Hence, it is opined that the position in Singapore is best to be followed since the Authority is not making it compulsory for the disputed parties to go through the mediation prior to the Tribunal. It is considered that by imposing the disputed parties to go through the mediation process first prior to the Tribunal would result to incurring of more cost to the disputed parties. Therefore, this may not reach the main objective of the Tribunal which is to have a short and cost effective way of resolving dispute. However, on the same note, there is also advantage in the three (3) tiered dispute resolution process of the NSW, Australia. By applying this process, it may lessen the number of back-log cases to be resolved at the Tribunal. Therefore, some matters can be resolved at the mediation or adjudication stage without proceeding to the Tribunal. Similar to the circumstances in Singapore, in the event that the dispute can be resolved at the mediation stage, the disputed parties may not incur high cost as compared to resolving the dispute in court.

\section{Qualifying Members of the Tribunal}

It is clearly stated in the provision of section 103(1) of the SMA that SMT members shall consist of the individual who shall be appointed by the Minister from amongst the members of the Judicial and Legal Service as a Chairman and Deputy Chairman. In addition, not less than twenty (20) other members shall be from the Judicial and Legal Service. In addition, section 103(2) clarifies that The Chairman and Deputy Chairman will take turns to sit in the tribunal. However, it is unclear as to whether the Chairman or Deputy Chairman shall have the same legal standing as the Sessions Court judges in Malaysia who, in their own right are having the jurisdiction to decide on cases of pecuniary jurisdiction of two hundred and fifty thousand (RM250,000) and below. Therefore, in view of the difference in the jurisdictional limits in these tribunals, it may in future lead to a potential dispute on the issue of the qualification of the Chairman or Deputy Chairman of the SMT. In view of the above, the position in Singapore is clear that the orders made by the Board shall be enforced in the same manner as a judgment of the District Court. This is clearly stated in Section 120(1) of the BMSMA, that:

Any order (including an interim order) made under this Part or the Land Titles (Strata) Act may, by leave of a District Court, be enforced against the person in the same manner as a judgment of that court, and where leave is so given, judgment may be entered in terms of that order.

Similarly, section 90(3) of the BMSMA, Singapore also provides that the President or Deputy President of the Strata Titles Board must be a qualified person within the meaning of the Legal Profession Act. However, the provision in section 89(4) of the BMSMA, Singapore has gone further by empowering the disputed parties to have a choice of members forming the Strata Titles Board. Nevertheless, it must be subjected to the approval of the President of the Strata Titles Board. The writer takes the view and agree with Teo Keang Sood in commenting that with the existence of the abovementioned provision, it will not only assist in ensuring that the composition of a Board is best suited to deal with the objections raised but also the impartiality of a Board is never put in doubt.

On the other hand, in NSW, Australia, in every tier of the dispute resolution process, the SSMA, NSW has also provides that the mediator, adjudicator and also members of the Tribunal must be held by a qualified person. The mediator as stated in Section 127 of the SSMA, NSW, is the Director-General or any person approved by the DirectorGeneral in writing to be a mediator for the purposes of mediation and resolution of disputes by the Director-General. It is further emphasised in the CTTT, NSW Fair Trading that it has qualified mediators who are skilled in dealing with the strata and community schemes disputes. As for the adjudicator, Chapter Six (6) Part Two (2) of the SSMA, NSW provides for the appointment of Strata Schemes Adjudicators. Section 217 of the SSMA, NSW states that the Minister may appoint Strata Schemes Adjudicators. Section 218 of the SSMA, NSW states that an Adjudicator has the functions conferred or imposed on an Adjudicator by or under Strata Scheme Management Act 1996 or any other Act. Section 219 of the SSMA, NSW states that an Adjudicator may delegate to the Registrar or Deputy Registrar the exercise of a function of the 
Adjudicator (other than this power of delegation). However, it was commented (Makinson, 2013) that the existing Adjudicators in the CTTT are not necessarily experienced in the field of strata law and may sometimes have little or no knowledge of it and very few could be described as experienced in strata law. This can be particularly frustrates the applicants who feel that their case has not been properly heard or have been misunderstood. Further to that, the applicants feel that they often receive unfair or contradictory orders as a result of their applications. It is further highlighted that it is common for Adjudicator's orders to leave no real resolution to a substantial number of complaints by owners and Owners Corporations, particularly in relation to those matters which have greater complexity of issues in dispute. Therefore, it is opined that an applicant, will exhaust all his or her avenues in the CTTT with no real outcome and then be required to transfer the proceedings to the Supreme Court, at a much greater expense, in order to obtain a comprehensive and effective resolution to their matter.

However, it is stated in the CTTT, NSW Fair Trading that the Tribunal members comprise of independent statutory officers who hear and determine applications brought before the CTTT in accordance with the law and based on the evidence presented. All Tribunal members, except for the Deputy Chairperson (Registry and Administration), are appointed by the Governor under Section 7 of the Consumer, Trader and Tenancy Tribunal Act 2001("CTTTA"). The Tribunal members are not eligible to be appointed as the Chairperson or the Deputy Chairperson (Determinations) unless the person is an Australian lawyer (Section 8(1) of the Consumer, Trader and Tenancy Tribunal Act 2001).

In the context of the above discussions and looking at Singapore and NSW, Australia, both jurisdiction have similar requirements as stipulated under the SMA; whereby the President or Deputy President (Singapore) and Chairperson or the Deputy Chairperson (NSW, Australia) involved in resolving the dispute must be a qualified person within the meaning of the Legal Profession Act of the respective countries. In that regards, it is proposed that the SMA also adds a provision as stipulated in the provision of CTTTA with regards to the requirement of qualifications and skills of the members of the Tribunal other than as a qualified person within the meaning of the Legal Profession Act. Section 8(3) of the CTTTA states as follows;

\begin{abstract}
In determining any such qualifications or skills, the Minister is to have regard to the following: (a) whether the person has the ability to exercise sound and fair judgment and to make objective and independent decisions based on the merits of the case,(b) whether the person has the ability to command the respect of the parties in proceedings,(c) whether the person has relevant expertise in one or more of the areas of the jurisdiction of the Tribunal,(d) whether the person has ability or experience in alternative dispute resolution procedures.
\end{abstract}

\title{
4. Disputed Parties Entitled to Claim
}

Based on the above composition of the SMT, it is viewed as an improvement in the provision of the SMA where the new provisions precisely state the persons who are entitled to file a claim to the Tribunal. Section 107 of the SMA states that no person other than the following persons shall be entitled to file a claim to the Tribunal: (a) a developer; (b) a purchaser; (c) a proprietor, including an original proprietor; (d) a joint management body; (e) a management corporation; (f) a subsidiary management corporation; ( $g$ ) a managing agent; and ( $h$ ) any other interested person, with the leave of the Tribunal. Hence, the SMA has made it possible on all the parties related to multi storey buildings to easily identify who has the right to bring the disputed matter before the SMT. In contrast, the provisions of the STA has failed to provide such clarity in its relevant provisions.

The SMA has added in the Section 107(h) that any other interested person, with the leave of the Tribunal shall be entitled to file a claim to the Tribunal. With such provision stipulated in the SMA, it will grant the parties that are not listed in Section 107(a)-(g), for instance a contractor who has dispute with the MC in the contract of rendering their service or supplying materials for the maintenance of the common property the right to claim before the SMT. Hence, it is opined that this is a pro-active provision whereby it gives the discretion to the Tribunal to determine parties that can file the claim other than the listed parties stipulated in Section 107(a)-(g) of the SMA. However, in order to make the SMA more comprehensive it can further spell out in detail the administrative and statutory bodies that have been discussed in Chapter Four (4) to file the claim before the SMT.

The provisions in the SSMA, NSW and BMSMA, Singapore are silent on the parties who are entitled to file a claim to the Tribunal. However, it is stated in the guideline of the CTTT, NSW Fair Trading that the applications to CTTT to resolve dispute after attempting mediation can be made by the lot owners, owners corporations and occupiers concerning strata, community and neighbourhood scheme disputes. On the other hand, the General Guide on Strata Living in Singapore, Building and Construction Authority, Singapore do not provide any guideline on who have the right to claim to the Tribunal for any dispute arises in the strata titles management. 


\section{Filing Fee for a Claim}

Currently, there are no provisions in the SMA or regulation to support the SMA in stipulating the filling fees payable by the disputed parties when making a claim to the SMT. In comparison to the position in Singapore and NSW, Australia, the filling fees for a claim in the Strata Titles Board is five hundred dollars (\$500) and for the CTTT, it is seventy eight dollars $(\$ 78.00)$ respectively. Therefore, in light of the above, it is suggested that it would be viable for the SMT to be charging a certain amount of fees when the disputed parties file a claim. This can be inserted in the regulation supporting the SMA.

Section 150 of Consumer Protection Act 1999 states that:

(1) The Minister may make such regulations as may be necessary or expedient for the purpose of carrying into effect the provisions of this Act.

(2) In particular and without prejudice to the generality of subsection (1), such regulations may (c) generally prescribe and provide for fees under this Act and the manner for collecting and disbursing such fees

Thus, as a guideline and to provide some comparison, the filling fees charged by the Homebuyers' Tribunal and the Consumer Tribunal can be taken into consideration. The disputed party only needs to pay a nominal fee of ten ringgit (RM10.00) for the Homebuyers' Tribunal and five ringgit (RM5.00) for the Consumer Tribunal in filling a claim. Taking into account of all the charges discussed above and the rationale of the establishment of SMT, it is opined that a fee of not more fifty ringgit (RM50.00) may be charged when filling a claim to the SMT. It is further opined that the said fees would be more aligned with the intention of the law maker of having disputes be resolved in more timely and efficiently with minimal costs.

\section{Conduct of Proceedings}

The provision in the SMA is considerably firm in disallowing disputed party to be represented in the Tribunal. It has been expressly stipulated in Section 110(2) of the SMA that:

No party shall be represented by an advocate and solicitor at a hearing unless, in the opinion of the Tribunal, the matter in question involves complex issues of law and one party will suffer severe financial hardship if he is not represented by an advocate and solicitor.

However, the provision has given some leniency by stipulating that in the event that a party is allowed to be represented by an advocate and solicitor, the other party shall also be entitled to be represented (Section 110(3) of the SMA). Therefore, it can be concluded that the said provision is fair and will be able to be balanced to both parties which are in dispute as provided in Section 113 of the SMA. The said section states:

the Tribunal shall act fairly and impartially as between the parties, giving each party a reasonable opportunity of presenting his case and dealing with that of his opponent.

In order for the Tribunal to run smoothly, it is substantial that the Chairman is given the liberty to conduct the proceeding of the Tribunal in a simple manner in order to resolve the disputes. Given the above, it has been ascertained that the SMA has explicitly indicated that the Tribunal may conduct the proceedings in a manner that is consider appropriate, necessary or expedient for the purpose of ascertaining the facts or law in order to determine a claim (Section 114(1) of the SMA). The powers conferred upon the Tribunal are outlined in Section 114(1) and Section 114(2) of the SMA. Section 114(2) explains that the powers conferred upon the Tribunal under subsection (1) shall include the following:

(a) to determine when and where any part of the proceedings is to be held;

(b) to determine the language or languages to be used in the proceedings and whether translations of any relevant documents are to be supplied;

(c) to make interlocutory orders;

(d) to determine the relevancy, admissibility and weight of any evidence without being bound by the rules of evidence under the Evidence Act 1950 [Act 56];

(e) to draw on its own knowledge and expertise;

(f) to order the provision of further particulars in a statement of claim or statement of defence; (g) to order the giving of security for costs;

(g) to make an on-site inspection of the building or land which form the subject matter of the claim;

(h) to order samples to be taken from, or any observation to be made of or experiment conducted upon, any 
parcel or common property or limited common property which is or forms part of the subject matter of the claim;

(i) to order the discovery and production of documents or materials within the possession or power of a party;

(j) to order the preservation and interim custody of any evidence for the purposes of the proceedings;

(k) to order the interrogatories to be answered;

(l) to order that any evidence to be given on oath or affirmation; and

(m) to summon the parties to the proceedings or any other person to attend before it to give evidence or to produce any document, records or other thing in his possession or otherwise to assist the Tribunal in its deliberations.

Notwithstanding the above, in the writer's view, there appears to be some room for further improvement in the proposed SMA. For instance, it is crucial to identify and define more clearly as to the word "reasonable" as stated in Section 115(2) of the SMA. It is observed and submitted that the word "reasonable" is still quite vague and it will potentially raise some uncertainty to the parties involved in a particular dispute. If we take that a step further, this may cause confusion during the time for hearing of the Tribunal. Therefore, in order to avoid any ambiguity, it is more appropriate for the SMA to spell out clearly on the period for the notice to be given to the parties.

In contrast to the position of Singapore, the BMSMA provides that a party to any proceedings may either appear in person before a Board or be represented by an advocate and solicitor of the Supreme Court, or such other person as the Board may allow, who may examine witnesses and address the Board on behalf of the disputed party (Section 94(1) of the BMSMA, Singapore). It further states that in the case of a management corporation or subsidiary management corporation, it may be represented by an advocate and solicitor of the Supreme Court, a member of its council or executive committee, as the case may be, or such other person as the Board may allow (Section 94(2) of the BMSMA, Singapore). These provisions in the BMSMA have enabled the Board, depending on the matter to be considered in the proceedings, to allow any person to represent the party concerned and to appear before the Board. Further to that, the Board would permit a person who is not a lawyer and who is involved in the day-to-day managing the strata scheme, for instance a managing agent, to better represent the disputed party, management corporation or subsidiary management corporation concerned.

Currently, in NSW, Australia, disputed parties involved in a strata or community scheme dispute is automatically entitled to be legally represented. However, a legal practitioner is generally not necessary and the disputed party can represent themselves at the CTTT. It is beneficial to note that NSW Fair Trading currently offers an informal 'duty advocate' type of service for those who attend mediation and need information about the law. It is vital to note that in NSW, Australia, there are an increasing number of parties realising the advantage in employing a specialist lawyer to act on their behalf in disputes. This is due to the fact that the legal representation can help to ensure arguments are presented in a clear and concise manner. However, the set-back is that it can add significantly to the cost and complexity of the proceedings. It can also place unrepresented parties at a disadvantage.

Therefore, it is hoped that with the leniency of the SMA as stipulated in Section 110(3) in allowing the disputed party to be represented in the event that another party is allowed to be represented by an advocate and solicitor, it will not jeopardise the spirit of the law in intending to have a less formal and costly proceeding.

\section{Awards of Tribunal}

It can be construed that the SMA has been drafted in such a way that the interest of the disputed parties is put as a priority. This can be seen in Section 117(1) of the SMA which explicitly states that:

The Tribunal shall make its award without delay and, where practicable, within sixty (60) days from the first day the hearing before the Tribunal commences.

Further to that, the Tribunal shall be required to give its reason for its award in the proceedings (Section 117(2) of the SMA). It can be deduced that the interest of the disputed parties are the utmost priority of the SMA since a criminal penalty will be charged on any person who fails to comply with the award made by the Tribunal (Section 123 of the SMA). It can be ascertained that with the severe criminal penalty imposed on any person who fail to comply with the award, it will set as a deterrent to the disputed party not to comply. However, it is detrimental to note that although the SMA has explicitly provides a provision of criminal penalty, it had failed to elaborate the procedure on the action to be taken by the parties claiming that the other disputed party has failed to comply with the award. Therefore, the law makers shall spell out clearly in the SMA the appropriate steps to be taken in order to convict the disputed party for non-compliance of the 
award made by the Tribunal.

The party to a proceeding who is not satisfied with the award given by the Tribunal shall be allowed to apply to the High Court with prior notice to the other party and the Tribunal to challenge the award (Section 121(1) of the SMA). The ground of the challenge is on the basis of serious irregularity which the court considers has caused substantial injustice to the applicant. It has been determined that the matters which may fall within the meaning of irregularities are failure by the Tribunal to comply with Section 113 of the SMA, failure of the Tribunal to deal with all the relevant issues that were put to it or uncertainty or ambiguity as to the effect of the award (Section 121(3) of the SMA). Comparing the practice of the Homebuyers' Claims Tribunal, the award is challenged by way of certiorari. This is a normal practice whereby an award of a Tribunal is to be challenged only in a form of prerogative writs that is by way of certiorari. Therefore, section 121(1) of the SMA is considered special since it allows a party to challenge the award before the High Court.

The CTTT, NSW Fair Trading has clearly stated that the duration for the matter to be resolved in the Adjudication process is within three (3) months after the lodging of the application with the CTTT. In the process of Adjudication, the parties are to lodge a written submission to the CTTT. The CTTT does not impose on the disputed parties a requirement to submit the written submissions with any specific format. Therefore, the written submissions may be in a form of hand or typed written and it may include attachments, for instance, reports and photos. The time frame for the submission period is generally twenty-eight (28) days. It is detrimental to note that in the Adjudication process, there is no hearing, and the adjudicator makes a decision based on the written submissions they receive. The Adjudicator makes an order and provides written reasons for their orders 'on the papers'. In the event that any of the disputed parties are not satisfied with the decisions of the Adjudicator, the party can appeal to the CTTT by making an application for Tribunal orders (Section 177 of the SSMA, NSW). Generally, an appeal must be lodged within twenty-one (21) days after the order takes effect. The time limit for an appeal can be extended only up to ninety (90) days after the order takes effect. It is stated in the CTTT, NSW Fair Trading that the disputed parties can expect the first hearing to take place within eight (8) weeks after lodging the application to the CTTT. In the event that party to a proceeding who is not satisfied with the orders of the Tribunal, the party shall be allowed to appeal only to the District Court (Section 200 of the SSMA, NSW). However, in Singapore, the BMSMA does not state the time frame for the Board to make an order.

Given the above, it can be deduced that the time frame for the Tribunal to make an order as stipulated in the SMA is considered to be short (two (2) months), (Section 117(1) of the SMA) as compared to the Adjudicator in NSW which is three (3) months. Therefore, it serves the objective of the SMA and the intention of establishing the Tribunal which is to resolve dispute in a short and cost effective manner.

It is also relevant to highlight that in the CTTT, NSW, the Adjudicator has the power to grant interim orders (Section 170(1) of the SSMA, NSW). Similar to the position in Singapore, the Board has the same capacity as the Adjudicator in NSW whereby it has the power to make an interim order (Section 118(1) of the BMSMA, Singapore). However, in Malaysia, the SMT is empowered to make an interlocutory orders as stated in Section 114(2)(c) of the SMA. Section 101(1) of the SMA provides that "interlocutory order" means an order that (a) is made pursuant to a claim to the Tribunal in the course of any proceeding of the Tribunal; and (b) is incidental to the principal object of that proceeding, and includes any direction about the conduct of that proceeding, but does not include any partial or interim order making a final determination in respect of that proceeding.

In consideration of the above, it can be construed that the interlocutory orders referred to under Section 114(2)(c) of the SMA is similar to the interim orders made by the Adjudicator of the CTTT, NSW under Section 170(1) of the SSMA, NSW and also the STB in Singapore under Section 118(1) of the BMSMA, Singapore. It is material to note that the interlocutory order made under the SMA may be deemed to be incidental to the principal object to the proceeding. Section 101(1) further provides that the interlocutory order does not include any partial or interim order making a final determination. Hence, the writer is of the view that interim order stipulated under Section 101(1) of the SMA is not similar to the SSMA, NSW and BMSMA, Singapore because the former refers to the making of a final determination as opposed to a temporary order in the respective later Acts. The writer is of the view that the use of the word "interim order" under Section 101(1) may cause confusion if reference is made to the SSMA, NSW and BMSMA, Singapore. Therefore, it is suggested that the word "interim" be deleted to create more certainty and avoid potential confusion in the future.

\section{Limitation Period}

Section 105(2) of the SMA provides that:

For the avoidance of doubt, the Limitation Act 1953 (Act 254) shall not apply to the proceedings of the Tribunal. 
Based on the above definition, it can be considered that it will not be in harmony with the intention of the statute of Limitation Act 1953. For actions relating to torts and contracts generally the period is six (6) years from when the cause accrued, which is stated in Section 6 of Limitation Act 1953. Generally the law of limitations is relevant to civil disputes. As such, an aggrieved person can seek to be compensated by the other party and, where appropriate, prevent the continuation of a wrongdoing. The right where the wrongdoing has ceased does not exist or last forever. The right must be exercised by going to the court and seeking the required remedy and relief within a specified period. However, the limitations do not operate in an entirely absolute manner. There are situations where the limitation period is extended because there is fraud or a mistake.

In comparison to the jurisdiction of the Homebuyers' Claims Tribunal, the claim must be brought up by a homebuyer not later than twelve (12) months pursuant to Section $16 \mathrm{~N}(2)$ of the Housing Development (Control \& Licensing) Act 1966 under the following circumstances: from (a) the date of issuance of the certificate of completion and compliance for the housing accommodation or the common facilities of the housing accommodation intended for subdivision, whichever is the later; (b) the expiry date of the defects liability period as set out in the sale and purchase agreement; or (c) the date of termination of the sale and purchase agreement by either party and such termination occurred before the date of issuance of the certificate of completion and compliance for the housing accommodation or the common facilities of the housing accommodation intended for subdivision, whichever is later. It shall be limited to claim that is based on 'cause of action' arising from the sale and purchase agreement or a previous dealing entered into between the homebuyer and a licensed housing developer. Similarly, in the Consumer Protection Act 1999, the jurisdiction of the Consumer Tribunal is limited to a claim that is based on a cause of action which accrues within three (3) years of the claim.

In view of the above, it can be said that the rationale behind the SMA stipulating that the Limitation Act 1953 shall not be applicable to the proceedings of the SMT, is probably to accommodate the disputed parties in the strata titles management to bring before the SMT any disputes whenever it arises. This is considered as a positive move since disputes in strata titles management may arise at any point in time during the life time of the parcel owners in the multi storey buildings. However, the writer is of the view that it is best for the SMA to insert some rules in this regards in the regulation of the SMA when it is regulated.

\section{Conclusion}

Having compared to the Australian and Singapore legislations and despite of some uncertainties and weaknesses in the provisions of SMA with regards to SMT, it can be concluded that upon the enactment of the SMA, the establishment of the SMT will be good and an expedient alternative for the parties in dispute to be assisted. The disputed parties will have an alternative channel to resolve their dispute, rather than resolving the dispute in court. The process of resolving disputes at the SMT can be seen and deemed as a privilege to the member of the SMT, on the basis that the provision in the SMA specifically provided a protection against any suits and legal proceedings (Section 145 of the SMA). It is hoped that the SMT will be established as soon as the proposed SMA has been enacted and promulgated as law together with the regulations to regulate the SMT. It is viewed that with the regulations in place, this will assist and facilitate the smooth implementation of the SMT. To that end, it is hoped that the SMT will potentially eradicate if not totally avoid unfortunate incidents such as that which transpired on the $16^{\text {th }}$ March 2013 involving the Chairman of the JMB Taman Sri Idaman, Penang. This is due to the fact that the unsatisfied party may have a channel to bring forward their dispute to be resolved other than to court. In the final analysis, it is submitted that this position is unlike the STB; which is as at the date of writing this paper has not yet been in existence.

\section{References}

Azlinor Sufian. (2012). "Housing Tribunals: Comparative Analysis of the Practices in Peninsular Malaysia, Sabah and Sarawak" (2012) Vol. 13 No. 2. International Journal of Business and Society 151-162.

Alice Christudason. (2013)."Optimisation of Land Use through Innovative Legislation in Singapore"http://www.prres.net/Papers/ Christudason_Optimisation_of_land_use_through_Inovative_le \%E2\%80\%A6.pdf viewed on 27 July 2013.

Alice Christudason. (2005)."Legal Framework for Collective Sale of Real Estate in Singapore - Pot of gold for investors" (2005) Vol. 28 No.2 Journal of Property Management \& Finance.

Alice Christudason. (1996)."Subdivided Builidngs - Developments in Australia, Singapore and England" (1996) Vol 45 International and Comparative Law Quarterly 343.

Alice Christudason. (2010). 'Controversial Strata Legislation: Catalyst for Housing Regeneration in Singapore' (2010) Special issue: Realising Rights in Housing, Land, and Planning Journal of Legal Affairs and Dispute Resolution in Engineering and Construction 
2.

Alice Christudason. (2008). 'Legislation Affecting Common Property Management in Singapore: Confusion or Solution through Fragmentation?' (2008) 26 (3) J. Prop. Manage.

Christudason. (2013)."Insecurity of Tenure - Erosion of Fundamental Rights of Strata-Titled Property Owners in Singapore" (2000) Vol.No.1 August Property, Land Use and Real Estate Law, http://papers.ssrn.com/sol3/papers.cfm?abstract_id=229566 viewed on 27 July 2013.

Christudason. (2005)."Impediments to the Success of Collective Sales: Lessons for the Property Consultant" (2005) Vol. 23 No. 4 Property Management.

Christudason. (2009)."Property Rights: Achieving a Fine Balance in Collective Sales of Strata Titles Development in Singapore" (2009) No.1 International Journal of Law in the Built Environment 1.

Dato' Cecil Abraham. (2013)."Alternate Dispute Resolution In Malaysia", at 3-6, http://www.aseanlawassociation.org/9GAdocs/ w4_Malaysia.pdf viewed on 11 June 2013.

Ishak Ismail. (2012)."Strata Management Bill Abetting Illegal Property Managers" http://www.freemalaysiatoday.com/category/ opinion/2012/10/04/strata-management-bill-abetting- illegal-property-managers viewed on 6 October 2012.

K Everton-Moore. (2006). A Ardill et. al., "The Law of Strata Title In Australia: A Jurisdictional Stocktake" 13 (2006) Australian Property Law Journal 13-14.

Makinson \& d'Apice. (2013). "Proposal to Amend the Strata Schemes Management Act 1996 and RelatedLegislation" http://nsw.stratacommunity.org.au/resources/345/MakDap\%20Strata\%20Discussion\%20Paper\%20(2).pdf viewed on 3 July 2013 at 22.

Noor Azian Binti Shaari. (2013) "Tribunals For Consumer Claims: The Malaysian Experience", Sixth Annual AIJA Tribunals Conference http://www.aija.org.au/Tribs03/Malaysia.pdf viewed on 11 June 2013;

Samsar Kamar Bin Abd Latif. (2002) "A Tribunal for the House Purchaser in the Revamped Housing Development (Control and Licensing) Act 1966" No 2(2002) The Journal of the Malaysian Bar XXXI.

Sharon Christensen and Anne Wallace. (2006). "Links between Physical and Legal Structures of Community Title Schemes and Disputes" 14 (2006)Australian Property Law Journal 94.

Teo Keang Sood. (2012). Strata Title in Singapore and Malaysia, Fourth Edition, Lexis Nexis (2012) at 756. 